\title{
New records of the rare glacial relict Eurytemora lacustris (Poppe 1887) (Copepoda; Calanoida) in atypical lake habitats of northern Germany
}

\author{
Gerhard MAIER*, Berit SPETH ${ }^{1 \dagger \dagger}$, Wolfgang ARP ${ }^{2)}$, Mandy BAHNWART ${ }^{3)}$ and Peter KASPRZAK ${ }^{4)}$ \\ Bureau of Aquatic Ecology, Brucknerstrasse 23, 89250 Senden, Germany \\ ${ }^{1)}$ Speth \& Speth GbR, Rothenhörn 9, 24647 Wasbek, Germany \\ ${ }^{2)}$ LimPlan, Gewässer- und Landschaftsökologie, Otawistrasse 19, 13351 Berlin, Germany \\ ${ }^{3}$ State agency for agriculture, environment and rural areas (LLUR) of Schleswig-Holstein, Hamburger Chaussee 25, 24220 Flintbek, \\ Germany \\ ${ }^{4)}$ Leibnitz Institute of Freshwater Ecology \& Inland Fisheries, Berlin, Department of Limnology, Alte Fischerhütte 2, OT \\ Neuglobsow, 16775 Stechlin, Germany \\ *e-mail corresponding author: gmaier-senden@t-online.de
}

\begin{abstract}
During monitoring investigations of lakes in Schleswig-Holstein (northern Germany) in 2000 and 2008, the calanoid copepod Eurytemora lacustris (POPPE 1887) was found in three lakes of the Ratzeburger Lake complex: the Kleine Küchensee, the Große Küchensee and the Große Ratzeburger See. The species has a broad geographic distribution but has become rare and endangered by eutrophication and global change. The lakes are mesotrophic (Gr. Ratzeburger See) and eutrophic (Kl. Küchensee, Gr. Küchensee) with cool $\left(<10{ }^{\circ} \mathrm{C}\right)$ hypolimnia; they have surface areas of 12.6, 0.2 and $1.8 \mathrm{~km}^{2}$ and a maximum depth of $24.4,12.8$ and $14.7 \mathrm{~m}$, respectively. All three lakes are shallower than lakes reported as typical habitats for E. lacustris. Oxygen conditions in the hypolimnion were different in the two years of investigation. In 2000, the oxygen concentration in summer (July) was zero from $13 \mathrm{~m}$ downwards in the Gr. Ratzeburger See and zero from $7 \mathrm{~m}$ downwards in the Kl. and Gr. Küchensee. In the year 2008 the hypolimnia of both lakes were well oxygenated in summer $\left(>1 \mathrm{mg} \mathrm{O} \mathrm{O}^{-1}\right)$. Food and physical conditions seem to be favourable enough to permit survival and reproduction of the species at least in spring. It remains unclear, however, whether the populations in the studied lakes are autochthonous. Eurytemora lacustris possibly invaded the lakes or was transported via a canal from the Schaalsee upstream, where a viable population exists.
\end{abstract}

Key words: calanoid copepod, endangered species, glacial relict, atypical habitat

\section{INTRODUCTION}

In Germany the genus Eurytemora is represented by three species, E. affinis (Poppe 1880), E. lacustris (Poppe 1887) and E. velox (Lilljeborg 1853). Among the three species E. lacustris is found exclusively in fresh waters while E. affinis and E. velox often prefer brackish waters (Kiefer 1978, Einsle 1993). Although $E$. lacustris has a broad geographical distribution, it occurs only in few, generally oligotrophic lakes which show particular morphological, chemical and physical characteristics (Weiler et al. 2003; Kasprzak et al. 2005, 2006; Arbačiauskas \& Kalytytė 2010). Most lakes where E. lacustris was observed are deep with a well oxygenated, cold hypolimnion (Pesta 1928). Weiler et al. (2003) and Kasprzak et al. (2005) concluded that $E$. lacustris is largely restricted to lakes with a maximum depth $>30 \mathrm{~m}$ where temperature in the hypolimnion does not exceed $10{ }^{\circ} \mathrm{C}$ and where oxygen concentration in the hypolimnion is $>1 \mathrm{mg} \mathrm{L}^{-1}$ during the summer. Eurytemora lacustris is a cold stenothermic and perennial species, which is unable to produce resting eggs and which often forms a population maximum in winter (e.g., Kiefer 1978). In summer this species is generally restricted to the cold hypolimnion (Naber 1933; Herbst 1953; Weiler et al. 2003).

\section{METHODS}

During a monitoring program conducted in Schleswig-Holstein (northern Germany) in the years 2000 and 2008 E. lacustris was recorded in three connected lakes of the Ratzeburger Lake complex: the Kleine Küchensee, the Große Küchensee and the Große Ratzeburger See (Speth 2001; Arp \& Maier 2009). Zooplankton was sampled in monthly intervals by vertical hauls from bottom to surface with a plankton net of 55 $\mu \mathrm{m}$ mesh size. Until now the three lakes were not known as habitats for the species.

\section{RESULTS}

Eurytemora lacustris can be distinguished from the other two species of the same genus occurring in Germany by e.g. by the lack of "wings" on the $5^{\text {th }}$ thoracic segment and the shape of the fifth leg (P5) of the male and female (Fig. 1). The Kl. Küchensee (which was sampled only in the year 2000) and the Gr. Küchensee have a surface area of 0.2 and $1.8 \mathrm{~km}^{2}$, a maximum depth of 12.8 and $14.7 \mathrm{~m}$ and a mean depth of 8.9 and 

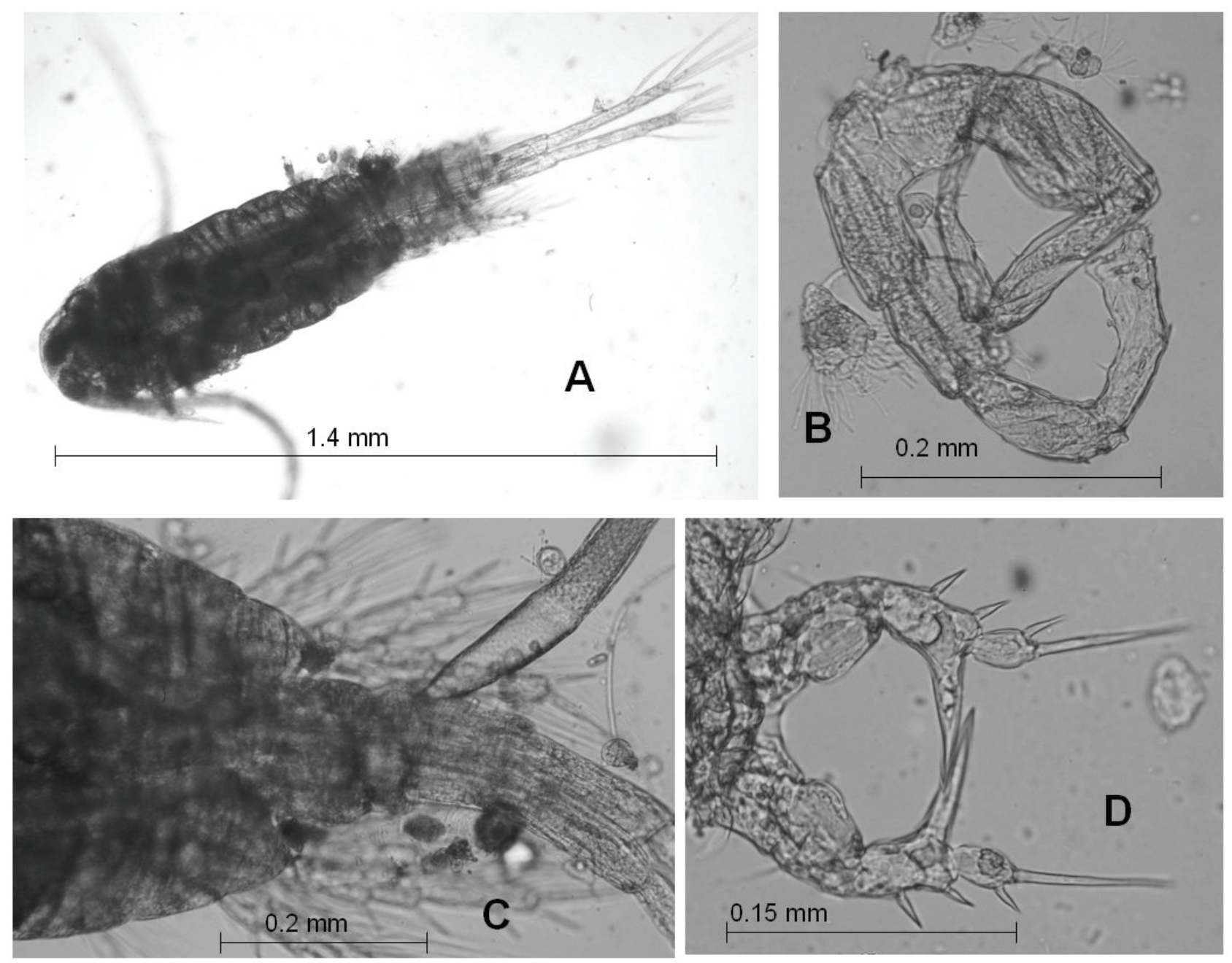

Fig. 1. Photographs of Eurytemora lacustris from the Gr. Küchensee viewed under a compound microscope. A) Male, habitus. B) Fifth pair of legs (P5) of the male. C) Female with attached spermatophore; region around the 5th thoracic segment. D) Fifth pair of legs (P5) of the female.

$8.5 \mathrm{~m}$, respectively. The Gr. Ratzeburger See is larger; it has a surface area of $12.6 \mathrm{~km}^{2}$, a maximum depth of $24.4 \mathrm{~m}$ and a mean depth of $11 \mathrm{~m}$ (e.g., Lanu 2002). The lakes are eutrophic (K1. Küchensee, Gr. Küchensee) to mesotrophic (Ratzeburger See). For example, concentrations of total $\mathrm{P}$ (average concentration during the growing season in the $1 \mathrm{~m}$ surface layer) are $40 \mu \mathrm{g} \mathrm{L}^{-1}$ in the Gr. Küchensee and $35 \mu \mathrm{g} \mathrm{L}^{-1}$ in the Gr. Ratzeburger See. Oxygen concentrations during summer in the hypolimnion in 2000 were zero from $13 \mathrm{~m}$ downwards in the Gr. Ratzeburger See and zero from $7 \mathrm{~m}$ downwards in the Kl. and Gr. Küchensee. In 2008, minimum oxygen concentrations in the hypolimnion were $>1 \mathrm{mg} \mathrm{L}^{-1}$ (>10\% saturation) in the Gr. Küchensee and the Gr. Ratzeburger See. No measurements/samples were taken in the Kl. Küchensee in this year. The highest water temperatures in the hypolimnion (April to August 2008) were $8-10{ }^{\circ} \mathrm{C}$ (Gr. Küchensee) and 7-10 ${ }^{\circ} \mathrm{C}$ (Gr. Ratzeburger See). Both lakes are connected with the Schaalsee, which is more than $70 \mathrm{~m}$ deep, via the Schaalsee canal (Fig. 2).
In the year 2000, E. lacustris was found in the Kl. Küchensee in March, in the Gr. Küchensee in March and in February, and in the northern part of the Gr. Ratzeburger See in April and May. Abundance was low in this year $\left(<1\right.$ ind $\left.\mathrm{L}^{-1}\right)$. In 2008 , the species was present in the Gr. Küchensee for a longer period of time in spring (March to May) and the maximum abundance (copepodids and adults; without nauplii) was higher than in the year 2000 (9.3 ind L $\mathrm{L}^{-1}$; Fig. 3). Females carried between 32 and 56 eggs; mean clutch size was 43.9 eggs female ${ }^{-1}(n=7)$. Males and all copepodid instars were also recorded from March to May. In the Gr. Ratzeburger See, E. lacustris was recorded from April to June and in September (Fig. 2). Here the abundance of E. lacustris was lower than in the Gr. Küchensee but higher than in 2000. Maximum abundance (copepodids

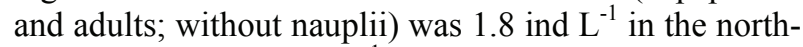
ern basin and 0.6 ind $\mathrm{L}^{-1}$ in the southern basin of the lake. Only one egg-bearing female, which carried 56 eggs was observed in the northern lake basin. However, males and all copepodid instars were observed in the 


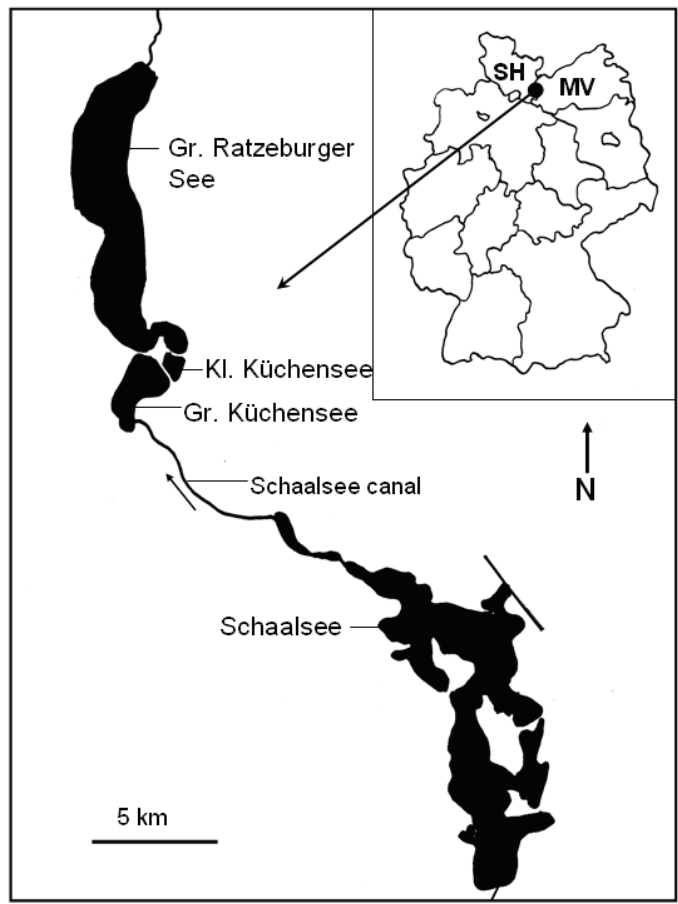

Fig. 2. Map of Germany (upper right corner) showing the position of the new sites of Eurytemora lacustis $(\mathrm{SH}=\mathrm{Schleswig-Holstein}$; MV = Mecklenburg Vorpommern). The more detailed map depicts the lake complex of Gr. Ratzeburger Lake, Kl. Küchensee and Gr. Küchensee, which are all connected via the Schaalsee canal to the Schaalsee upstream.
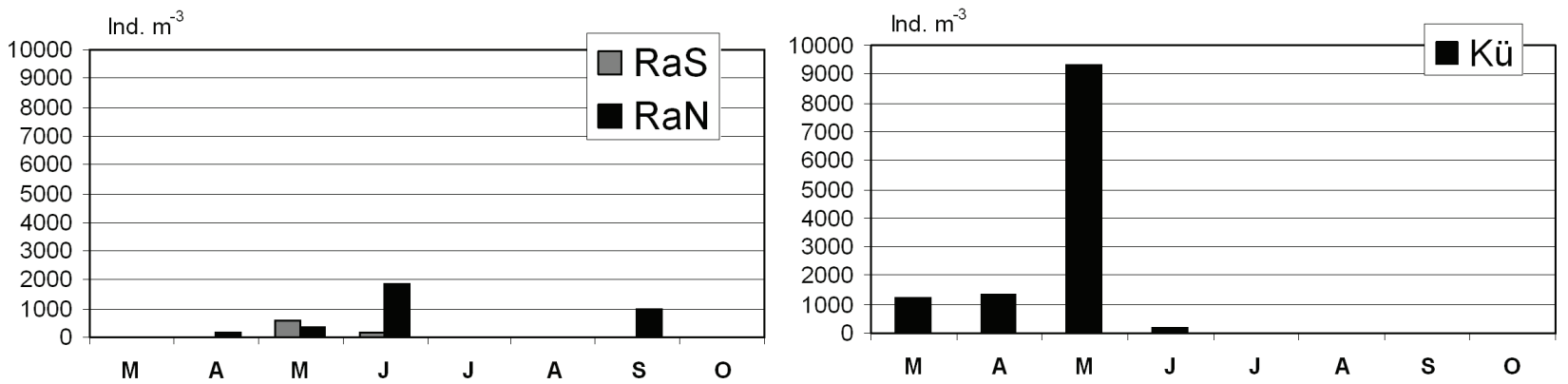

Fig. 3. Abundance of Eurytemora lacustris in the Gr. Ratzeburger See ( $\mathrm{RaN}=$ northern lake basin; $\mathrm{RaS}=$ southern lake basin $)$ and in the Gr. Küchensee (Kü) in individuals $\mathrm{m}^{-3}$ in 2008.

lake. During the peak abundance of E. lacustris in both lakes the phytoplankton was dominated by diatoms (high biovolumes in March) and cryptophytes (dominant in May during the clear water phase). Important species (by biovolume) were Cyclotella radiosa (Grunow; Lemmermann 1900) Stephanodiscus alpinus (Hustedt 1942) and Asterionella formosa (Hassall 1856) accompanied by small cryptophyte flagellates (mainly different Cryptomonas and Rhodomonas species). The maximum phytoplankton biovolume in March was approximately $14 \mathrm{~mm}^{3} \mathrm{~L}^{-1}$ in the Gr. Küchensee and approximately 11 (northern basin) to $16 \mathrm{~mm}^{3} \mathrm{~L}^{-1}$ (southern basin) in the Gr. Ratzeburger See. In April the phytoplankton biovolume dropped to approximately $2.5 \mathrm{~mm}^{3}$ $\mathrm{L}^{-1}$ (Gr. Küchensee) and $1 \mathrm{~mm}^{3} \mathrm{~L}^{-1}$ (Gr. Ratzeburger See), before decreasing further to $0.3 \mathrm{~mm}^{3} \mathrm{~L}^{-1}$ in May in both lakes.
The lakes contain a large number of zooplankton species. Cladocerans were represented by Bosmina coregoni coregoni (Baird 1857), Bosmina coregoni gibbera (Schoedler 1863), Bosmina longirostris (O.F. Müller 1785), Chydorus sphaericus (O.F. Müller 1785), Daphnia cucullata (Sars 1862), Daphnia galeata (Sars 1864), Daphnia $\times$ krausi (Floessner 1993), Diaphanosoma brachyurum (Lievin 1848) and Leptodora kindtii (Focke 1844). Copepods present (besides E. lacustris) were Eudiaptomus gracilis (G.O. Sars 1863), Eudiaptomus graciloides (Lilljeborg 1888), Acanthocyclops sp. group robustus (G.O. Sars 1863), Cyclops abyssorum (G.O. Sars 1863), Cyclops kolensis (Lilljeborg 1901), Cyclops vicinus (Uljanin 1875), Diacyclops bicuspidatus (Claus 1857), Mesocyclops leuckarti (Claus 1857), Thermocyclops crassus (Fischer 1853) and Thermocyclops oithonoides (G.O. Sars 1863). Dur- 
ing the peak abundance of E. lacustris in spring, the dominant crustaceans were $B$. longirostris, $D$. galeata, Eudiaptomus spp. and Cyclops spp. The other species listed above were rare $(D . \times k r a u s i, A$. sp. group robustus, D. bicuspidatus) or more frequently found during the summer and/or autumn. The average zooplankton biomass (March to October) was approximately $0.4 \mathrm{mg} \mathrm{L}^{-1}$ (Gr. Küchensee and Gr. Ratzeburger See N) and $0.25 \mathrm{mg} \mathrm{L}^{-1}$ (Gr. Ratzeburger See S) which confirms the eutrophic to mesotrophic condition of the lakes. For more details see Speth (2001) and Arp \& Maier (2009).

\section{DISCUSSION}

Eurytemora lacustris has become rare and endangered in Germany. The species is threatened by eutrophication and global change. The findings in the Gr. Ratzeburger See, the Kl. Küchensee and the Gr. Küchensee are new for Schleswig-Holstein. Formerly, E. lacustris was present in several lakes such as the Gr. Plöner See or the Selenter See but the species disappeared from these lakes possibly as a consequence of combined effects of eutrophication and global warming (cf. Weiler et al. 2003 and citations therein). The lakes studied here do not show all the characteristics typical for habitats with viable populations of E. lacustris as described in Weiler et al. (2003) and Kasprzak et al. (2005). They are shallower than $30 \mathrm{~m}$, however low temperatures and sufficient food resources seem to permit survival and reproduction at least in spring. The reason why oxygen concentrations in the hypolimnion were unfavourable in 2000 but favourable in the year 2008 cannot be explained at the present stage. Therefore, it remains unclear whether the populations in the studied lakes are autochthonous. It is possible that $E$. lacustris invaded the lakes or was transported via the Schaalsee canal from Schaalsee, which is located upstream and which hosts a viable population (Kasprzak et al. 2005). This assumption would support the hypothesis of Weiler et al. (2003) and Kasprzak et al. (2005) that most shallow lakes where E. lacustris is found are connected via canals with deep lakes which contain viable populations of the species. A further argument for the transport/invasion hypothesis is that no specimens of E. lacustris were found in summer in the studied lakes. Furthermore, abundance decreased downstream from the "input" of Schaalsee into the Gr. Küchensee to the Gr. Ratzeburger See, which also supports the transport/invasion hypothesis. On the other hand, the fact that E. lacustris was found in both years where the "Ratzeburger Lakes" were studied and the fact that the species was present in spring and autumn in the northern basin of the Gr. Ratzeburger See suggests that the species might be present regularly in these lakes. Since E. lacustris is a glacial relict with decreasing populations, further and more intensive studies are necessary to maintain up-to-date knowledge on the status of the species and on the effects of large-scale changes to glacial relicts and other endangered species.

\section{ACKNOWLEDGEMENTS}

We thank the LLUR Schleswig-Holstein for the permission to publish these data and for financial support. Particular thanks go to two anonymous reviewers for their valuable comments on an earlier draft of this manuscript. Thanks go also to Tom Shatwell for linguistic improvements of the text.

\section{REFERENCES}

Arp, W. \& G. Maier. 2009. Untersuchungen des Phyto- und Zooplanktons schleswig-holsteinischer Seen 2008. LLUR Report Limplan \& Bureau of Aquatic Ecology: 252 pp.

Arbačiauskas, K. \& D. Kalytytè. 2010. Occurrence and interannual abundance variation of glacial relict calanoids Limnocalanus macrurus and Eurytemora lacustris in Lithuanian Lakes. Acta Zoologica Lituanica, 20: 61-67.

Einsle, U. 1993. Crustacea, Copepoda - Calanoida und Cyclopoida. In: Süßwasserfauna von Mitteleuropa. Gustav Fischer Verlag: 208 pp.

Herbst, H.V. 1953. Untersuchungen zur quantitativen und qualitativen Verteilung des Zooplanktons. Gewässer und Abwässer, 1: 61-69.

Kasprzak, P., C. Reese, R. Koschel, M. Schulz, I. Hambaryan \& J. Mathes. 2005. Habitat characteristics opf Eurytemora lacustris (Poppe, 1887) (Copepoda, Calanoida): The role of lake depth, temperature, oxygen concentration and light intensity. Internat. Rev. Hydrobiol., 90: 292-309.

Kasprzak, P., C. Reese, R. Koschel, M. Schulz, I. Hambaryan \& J. Mathes. 2006. Glacial relicts in NE-German lakes: Habitat characteristics of Eurytemora lacustris (Copepoda, Calanoida). IGB Report: 151-160.

Kiefer, F. 1973. Ruderfußkrebse. In: Einführung in die Kleinlebewelt. Kosmos-Verlag Franckh-Stuttgart: 99 pp.

Kiefer, F. 1978. Copepoda. In: Das Zooplankton der Binnengewässer 2. Teil. E. Schweizerbart'sche Verlagsbuchhandlung; Nägele und Obermiller: 208 pp.

LANU 2002. State agency for nature and environment of Schleswig-Holstein. Zustand und Belastungsquellen Ratzeburger Seen. Lake Report No. B51: 129 pp.

Naber, H. 1933. Die Schichtung des Zooplanktons in holsteinischen Seen und der Einfluß des Zooplanktons auf den Sauerstoffgehalt der bewohnten Schichten. Arch. Hydrobiol., 25: 81-132.

Pesta, O. 1928. Krebstiere oder Crustacea. I. Ruderfüßer oder Copepoda.- In: F. Dahl (Ed.), Die Tierwelt Deutschlands. Part 9. G. Fischer Verlag, Jena: 136 pp.

Speth, B. 2001. Untersuchung des Phyto- und Zooplanktons im Ratzeburger See, Domsee, im Kleinen Küchensee und im Großen Küchensee. LANU Report, Speth \& Speth Gbr: $36 \mathrm{pp}$.

Weiler, W., P. Kasprzak, M. Schulz \& D. Flössner. 2003. Habitat requirements of Eurytemora lacustris (Copepoda, Calanoida) and implications for its distribution. Arch. Hydrobiol. Spec. Issue, Advanc. Limnol., 58: 203-214. 